\title{
Stakeholder collaboration in improving integrated basic occupational in health services supply chain in community health center
}

\author{
Isyatun Mardhiyah Syahria ${ }^{a^{*}}$, Badaruddin $^{a}$, Surya Utama $^{a}$ and Zulfendria
}

${ }^{a}$ Universitas Sumatera Utara, Medan, Indonesia

\begin{tabular}{l}
\hline C H R O N I C L E \\
\hline Article history: \\
Received May 2, 2020 \\
Received in revised format \\
September 18, 2020 \\
Accepted October 292020 \\
Available online \\
October 29 2020 \\
\hline Keywords: \\
Occupational health and \\
safety \\
Performance \\
Stakeholder \\
Community health center
\end{tabular}

\section{Introduction}

The health and safety of workers is a pillar in encouraging business competitiveness. For the micro and small business sectors, worker health and safety are crucial because workers' absence will disrupt activities and production capacity. Data from the Ministry of Cooperatives and SMEs (2020) shows that micro and small businesses have a share of around $99.90 \%$ (64.13 million), with a gross domestic product (GDP) contribution of 47.3\%. It estimated that Micro and Small Enterprises absorb around 113.3 million $(93.88 \%$ ) of the workforce. This data shows the importance of managing occupational health efforts for micro and small businesses to support the national economy. Unfortunately, the importance of managing OSH efforts in the informal sector and small businesses have not received much serious attention from the government. Some researchers found that many work accident cases occur in small industries and informal workers (Kelloway \& Cooper, 2011; Ahmad, 2017; Zulkifly, 2018). Micheli and Cagno's research (2010) found that health and safety problems are more

\begin{abstract}
This study aims to describe the collaboration of stakeholder roles and analyzes the influence of government, Micro \& Small businesses and workers to improve the performance of Occupational Health and Safety (OHS) officers in community health center. The study is a survey with a crosssectional design to measure the influence of stakeholders' role on the performance of occupational health efforts. The study sample was 80 people, namely all OHS officers from the community health center $(\mathrm{CHC})$ in the city of Medan. The independent variables in this study are the role of government (X1), the role of micro and small business (X2), the role of the workers using a questionnaire that has been validated with interval scales $1-5$. Hypothesis testing is based on using structural equation modeling path analysis and analysis is performed using PLSSEM, Smart PLS 3.0. Direct test results show that the government has not played a significant role in Micro \& Small Business and the role of workers. The government only plays a significant role in the performance of OHS officers. Micro \& Small businesses significantly influence workers' role, but it has not significantly affected OHS officers' performance. The role of workers
significantly influences the performance of OHS officers. Test results indirectly show the critical role of collaboration between stakeholders. Although it has not shown a significant effect, there is an increase in the significant value on the performance of officers. The finding confirms the need for seriousness and the importance of collaboration among stakeholders. The research needs to be expanded by involving all OHS officers up to sub-health centers, and other districts/cities with the same characteristics. The study has only investigated at community health center. Policy recommendations are given for managing an integrated occupational health service program in community health center involving all stakeholders in Medan.
\end{abstract}

(C) 2021 by the authors; license Growing Science, Canada. 
common in small industries, where the majority of workers involved did not have good enough safety knowledge. Cagno, Micheli, \& Perotti (2011) found that the majority of workers in small industries reported having an occupational accident.

Work safety and health implementation are some of the critical factors in increasing work productivity. Work accidents experienced by workers reduce productivity (Ling et al., 2019; Silverberg et al., 2018). The high incidence of occupational accidents is related to the low implementation of occupational health services and work environment factors (Rantanen, Lehtinen, \& Iavicoli, 2013; Muda et al., 2019). This opinion is supported by Dijk \& Buijs's (2017) research, which concluded that informal sector workers do not work contracts, and social security is often exposed to poor working environment conditions so that the risk of work accidents. This condition illustrates the importance of occupational health efforts so that workers get Occupational Health and Safety (OHS) services to reduce the risk of occupational diseases and work accidents. Research by Burton (2010) and Buijs \& Dijk (2014) stated the need for occupational health efforts for workers to protect them from accidents and occupational diseases. This opinion is in line with Laal et al. (2019) that the safety program will reduce the number of workplace accidents. Rantanen (2005) states that the Occupational Health Efforts Program must be supported by providing adequate infrastructure and involving all implementing actors. For this reason, collaboration and active participation from all stakeholders (central government, regional, business, and workers) needed. According to Chen et al. (2010), health service coverage will increase due to the active involvement of the government, employers, and community workers by collaborating with OSH officers. Ghuzdewan and Damanik (2019) recommended the need for government, business owners, and workers to play an active role in raising awareness of the importance of OHS in order to prevent and reduce workplace accidents. Various forms of roles and support that stakeholders can provide in occupational health efforts include the active participation of employers and workers in planning the promotion and development of OHS (Mchunu, 2012). The government has provided occupational safety and health training to OHS program officers to impact the sustainability and success of the programs implemented positively (Denny, 2012). This situation shows the importance of stakeholder support in improving the performance of the OHS program. Puplampu \& Quartey's (2012) research results show that the government's role in formulating a comprehensive national OHS policy framework does not lead to the optimal development of OHS HR capacity.

In Indonesia, the Community Health Center (CHC) is responsible for public health in its work area (MOH Regulation no. 43 of 2019). Worker health is part of the CHC services in the form of occupational health efforts (MOH RI, 2007; MOH, 2010). The Republic of Indonesia's Ministry of Health's Report (2017) shows that nationally the CHC conducting essential occupational health efforts has not yet reached the target set. The Directorate of Occupational Health and Sports (2016) reports that occupational accidents and cases of occupational diseases are still occurring in Indonesia. Syahri \& Fitria's research (2018) showed that as many as 68,75 percent of fishers who were members of Occupational Health Posts in Medan experienced health-related complaints at work. In particular, OHS research in the area of work at the CHC is limited to the issue of the impact of occupational health interventions in Indonesia (Denny, 2012), the activities at occupational health posts (Syahri \& Fitria, 2019), OHS at occupational health posts' fishermen (Syahri \& Fitria, 2018) and the implementation of community-based occupational health workers (Ferdiana et al., 2019). The previous research still did not see the role of stakeholders and their impact on the performance of CHC staff. Research on the role of stakeholders in OHS is minimal (Freeman, Harrison, Wicks, Parmer, \& Colle, 2010). This condition shows that research is needed to provide solutions and improve work safety performance, primarily to protect workers in the small and informal sectors. Based on this condition, it is crucial to research to assess stakeholders' role and their impact on the performance of OHS officers in CHC. This study aims to see the direct and indirect effects of each stakeholder in improving OHS officers' performance in the informal, micro, and small business sectors. This research also provides solutions and seeks collaboration models of stakeholders needed to improve OHS officers.

\section{Literature Review}

\subsection{Stakeholder \& Performance Theory}

Armstrong (2006) states that performance can be influenced by organizational support or coworkers involved in the organization. According to Cascio \& Aguinis (2008), stakeholders can also influence organizational performance. Freeman et al. (2010) also stated that stakeholder involvement could influence organizational goals. Buse et al. (2012) asserted that all interested parties and involved in each stage of the policy development cycle, both those who formulate, advocate and implement to be affected by a policy both directly or indirectly, negatively or positively are referred to with stakeholders. Freeman et al. (2010) emphasized that all stakeholders involved must obtain information related to the organization's value creation activities. The role of stakeholders will encourage improved performance and better organizational value creation (Sachs \& Ruhli, 2011; Harrison \& Wicks, 2013; Muda et al., 2018). On occupational health, the added value of an organization can be reflected by improving the health of workers and decreasing occupational accidents through OHS activities. Other efforts made by stakeholders to create added value and improve performance can be made by managing and improving existing human resources (Baumfield, 2016). Tai, Wang, \& Chang (2014) said that consistent support from stakeholders in providing high-quality facilities and interactions and establishing shared goals would improve performance. The results of Doloi (2012) and Adnan's (2012) research found that stakeholders' role influences program performance. Stakeholders play an essential role in improving the performance of OSH programs. High stakeholder involvement will increase the chances of success of the OSH program (Chen et al., 2010; Auvinen, Kohtamaki, \& Ilvesmaki, 2012). Lack of 
support from the government and employers will cause a decrease in OHS performance (Manothum \& Rukijkanpanich, 2010; Puplampu \& Quartey, 2012). For this reason, it is necessary to monitor and collaborate with various stakeholders to improve OHS (Jahangiri et al., 2016).

\subsection{Occupational Health and Safety Performance}

According to WHO (2001), performance indicators for work health services oriented towards reducing risk and preventing injury or disease. Beriha, Patnaik, \& Mahapatra (2012) measure OHS performance based on the implementation of preventive procedures, including hazard assessment and OHS risk management, measurement, and improvement of a continuous work environment, work environment surveillance, and health checks. Cameron and Hare (2013) measures performance through work achieved by OHS officers, which includes OHS risk assessment, recording and reporting, and work accident investigation results. Rafiei et al. (2015) measure work success based on workplaces that have received occupational health services, health inspection activities on workers, and inspection of the work environment. Pawłowska (2015) measures performance using lagging indicators (accident rates) and leading indicators (occupational health and safety activities. Mohammadfam et al. (2016) explain that performance is measured by looking at work results in the form of OHS activities in the workplace. The Ministry of Health of the Republic of Indonesia (2012) emphasized that one indicator of the success of occupational health implementation is the formation of the occupational health post in the work area. So, the Occupational Health Post's application of activities can integrate with other health programs (Ministry of Health, 2015).

\subsection{The Role of Stakeholder in Occupational Health and Safety}

According to Chen et al. (2010), to improve occupational health efforts, the government needs to allocate sufficient budget, conduct OHS training, and develop an OHS policy system. Some researchers such as Rantanen (2007); Buijs, Gunnyeon, \& Weel (2012); and Frieden (2013) stated that the government has a vital role in increasing OSH efforts. Various government roles include overseeing, training, improving the work environment, working with employers and workers, strengthening policies to develop occupational health services, disseminating information related to health, and improving health through a collaboration involving the entire stakeholder. Vinberg et al. (2017) explained, to improve OHS services in small industries requires cooperation between occupational health service providers. In Indonesia, the provider of occupational health services for micro and small businesses is the CHC. Furthermore, Vinberg, Hansen, Hedlund, \& Landstad, 2017 said that service providers are essential partners to educate companies in OHS. The private sector also plays a role in health development, particularly the implementation of OHS for business owners or administrators applied in their workplaces. Chen et al. (2010) state that employers have an essential role in providing support for the implementation of occupational health services and facilities as well as supervision of the work environment. Putri (2013) states that the company plays a role in implementing OHS activities through the installation and attachment of danger symbols, providing health facilities, and providing light fire extinguishers. According to Cagno et al. (2011), companies or managers must play a role in planning and supporting OHS activities by improving the work environment in their workplaces, providing facilities and monitoring and evaluating OHS activities in their companies. According to Somad (2013), business owners, through managers, can play an active role in OHS culture and foster OHS. According to Harris et al. (2012) The role of the company in OHS is implementing the system, improving management, monitoring workers' actions towards OHS. Workers are not only as an object in health development but also as a subject in determining the success of healthy development. Dessler (2017) explains that employee involvement is one of the keys to organizational success. Participation in the implementation of health promotion, care, occupational health, and safety (Ledikwe et al., 2018). The role of workers is involved in planning, implementation, and supervision (EU-OSHA, 2012), implementation (Soehod, 2008). Worker participation takes place in the early stages of planning and intervention activities (Charalabidis \& Koussouris, 2012; Yazdani et al., 2017). Participation in designing and implementing prevention-related activities (Walters \& Wadsworth, 2017). Implementation of safety at work (Curcuruto, 2016).

\section{Methods}

This study was a survey with a cross-sectional approach. Namely, the research aims to measure the influence of stakeholders' role on the performance of occupational health efforts in Medan, Indonesia. In this study, Respondents included all OHS program implementers in the community health center, as many as $80 \mathrm{OHS}$ officers. The independent variable is the role of stakeholders consisting of the government (X1), the role of the private sector (X2), and the role of the community (X3). The dependent variable of this study is the performance of OHS officers (Y). Research data collection instruments using a questionnaire using interval scale 1-5. Distributed questionnaires have fulfilled the validity and reliability requirements. The role of government is measured by Controlling, OSH training, budget availability, OSH policy and cooperation (Chen et al., 2010; Frieden, 2013; Chen et al., 2010; Denny, 2012; Vinberg et al., 2017). Twenty-three questions represent government role indicators. The industry's role is measured by the availability of facilities, implementation, and Controlling of OHS programs (Harris et al., 2012) and (Cagno, Micheli, \& Perotti, 2011). The role of this industry developed into ninequestion items. The role of workers is measured using indicators of involvement in planning, implementation, and Controlling (EU-OSHA, 2012; Ledikwe et al., 2018; Charalabidis \& Koussouris, 2012; Yazdani et al., 2017; Walters \& Wadsworth, 2017; Curcuruto, 2016). An indicator of the role of workers represented by nine questions. Performance measured through the implementation of hazard identification, workers' health examination, workplace measurement, OHS 
promotion, workplace development, recording and reporting (Beriha et al., 2011; Cameron \& Hare, 2013; Rafiei et al., 2015; Mohammadfam et al., 2017; Pawłowska, 2015). Twenty-two question items represent performance indicators. Data were analyzed using Smart PLS 3.0.

\section{Result and Discussion}

\subsection{Descriptive statistics}

The number of respondents in this study was 80 respondents with the composition of male respondents $(9,75 \%)$ and women $(92,50 \%)$. Based on Fig. 1, it can be seen that women are the most. The majority of respondents' background education is undergraduate $(71,25 \%)$, Age $36-45(38,75 \%)$, and job experience as occupational safety and health officer in community health centers $<5$ years $(82,50 \%)$.

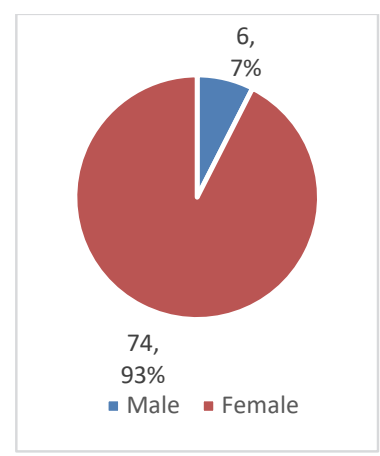

Gender

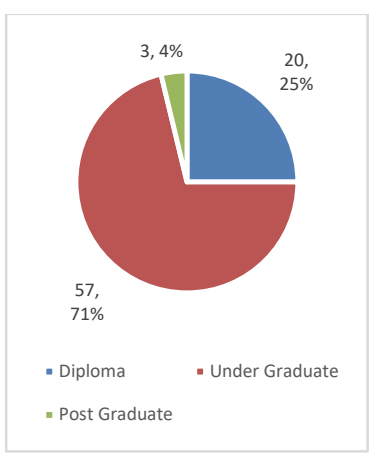

Educational background

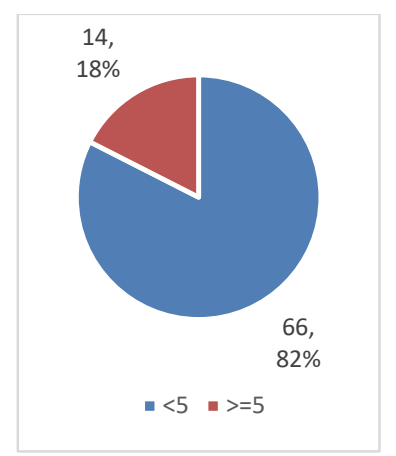

Job experience

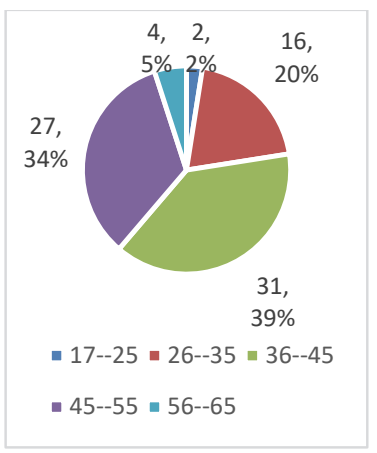

Age

Fig. 1. Personal characteristics of the participants

Table 1 illustrates that the highest average value of the role carried out by the government is controlling as many as 2.84 (enough categories), and the lowest is regulating that is 2.38 (unfavorable categories). This study's results indicate that the role of government in producing OHS policies is still not good enough, so it needs to be improved. The lack of an OHS policy issued by the local government has made OHS activities in Medan city, showing that the OHS program has not yet become a priority. The OHS plan that will be formulated should be able to improve coordination and partnerships among stakeholders. Besides, the resulting OSH Policy should empower workers to improve their occupational safety and health culture and encourage employers to participate in the application of OSH in the workplace actively. This OHS policy is significant to enhance the implementation of occupational health in the regions (Mandal, 2009; Chen et al., 2010; Mchunu, 2012). According to Rantanen, Lehtinen, \& Iavicoli (2013), the OSH policy established by law should require employers to be responsible for implementing OSH in the workplace. Based on the role of micro \& small business, the highest average value is an activity, and the lowest is controlling. These results indicate that business owners must seriously increase the supervision of the implementation of occupational health. The results of this study also show that business owners are still not optimally carrying out OHS supervision in the workplace. They even consider that the implementation of OHS is the responsibility of the $\mathrm{CHC}$ and the government. Business owners tend to pursue production targets still. This supervision should be carried out every day during the production process, not only when OHS officers visit and check. According to Ndjoulou, Desmarais, \& Pérusse (2015), Some supervisory models that can be developed and are the responsibility of business owners are the regulatory approach, economical approach, the work of the health and safety management system, and the sustainable development approach with a progress model.

Table 1

Descriptive statistics

\begin{tabular}{|c|c|c|c|c|c|c|c|}
\hline Goverment & Controlling & Training & Cooperating & Budgeting & Regulating & & Mean \\
\hline Avarage & 2.84 & 2.81 & 2.71 & 2.52 & 2.38 & & 2.65 \\
\hline Micro \& Small Business & Facilitating & Implementation & Controlling & & & & \\
\hline Avarage & 2.68 & 3.0 & 2.25 & & & & 2.64 \\
\hline Workers & Planning & Implementation & Controlling & & & & \\
\hline Avarage & 2.13 & 2.95 & 2.36 & & & & 2.48 \\
\hline Performance of OHS' officer & $\begin{array}{l}\text { Hazard } \\
\text { Identification }\end{array}$ & $\begin{array}{l}\text { Workers' Health } \\
\text { Examination }\end{array}$ & $\begin{array}{l}\text { Promotion of } \\
\text { Occupational Health } \\
\text { and Safety }\end{array}$ & $\begin{array}{l}\text { Workplace } \\
\text { Development }\end{array}$ & $\begin{array}{l}\text { Workplace } \\
\text { Measureme } \\
\text { nt }\end{array}$ & $\begin{array}{l}\text { Reporting } \\
\text { and } \\
\text { Recording }\end{array}$ & \\
\hline Avarage & 2.53 & 2.89 & 2.87 & 2.73 & 1.75 & 3.11 & 2.65 \\
\hline
\end{tabular}

Source: Results of Research, 2020 (Processed Data). Scale 1-5

Based on the role performed by workers, the highest value is the activity, and the lowest is planning. These results indicate that workers are still lacking the initiative to participate in planning OHS activities. If workers actively contribute to OHS planning, the OHS program implemented will be better targeted because it suits the needs and problems faced at the workplace. Lane, Leader, Bell, Smith, \& Worth (2000) show that employee involvement in the planning process and activity 
recommendations will be significant in providing solutions to OHS problems. Mojapelo \& Mafini (2016) also stated that workers. need to be actively involved in OSH planning. Thus, they will be responsible for implementing the OHS program and reporting work accident cases. The highest average score of performance is reporting and recording, and the lowest is workplace measurement. Workplace measurement is fundamental to determine the condition of the work environment. According to Soucie (2012), surveillance data can use to identify risk factors and be used to intervene in health programs. Andersen et al. (2019) noted that inspection activities with a useful measurement of the work environment would reduce injuries. The low performance of officers on surveillance in measuring the work environment must be improved. The health department must improve the facilities and completeness of the work environment inspection as well as increase the skills and knowledge of human resources in the field of work environment measurement.

\subsection{Outer Model}

Evaluation of models in PLS uses the outer model and the inner model. Chin (1998) states the outer model to assess the validity and reliability of the model. The construct of validity shows how well the measurements and the results obtained are by the theory used. Construct validity consists of convergent validity and discriminant validity (Hair, Hult, Ringle, \& Sarstedt, 2017). The validity of convergence can be seen from reflective indicators. Indicators can be considered reliable, assuming they have a correlation value above 0.7 . However, if the specific indicator value is in the amount of $0.4-0.6$, it is still acceptable if the scale is still in the development stage (chin, 1998). Discriminant validity can be seen based on the Fornell-Lesser criteria and Average Variance Extracted (AVE). AVE shows that the structure describes an average of more than half the variants in size. AVE results also must show that all variables have similarities above 0.5. Moreover, it indicates that the model used meets the validity requirements - the reliability constructs measured by composite reliability and Cronbach's alpha. The composites serve as proxies for the scientific concept, which has studied. Composite reliability varies from 0 to 1 . Values close to 1 indicate a higher level of reliability. In general, it interpreted in the same way as alpha from Cronbach. The Composite Reliability results show all variables above 0.7. Composite Reliability results show all variables above 0.7 means that the construct is declared reliable. Cronbach Alpha provides reliability calculates based on the interrelations discovered in the indicator. Fig. 2 and Table 2 show that all test indicators on the outer model have met the requirements.

Table 2

Reliability and Validity

\begin{tabular}{|c|c|c|c|c|c|c|}
\hline & $\begin{array}{l}\text { Cronbach's } \\
\text { Alpha }\end{array}$ & rho_A & $\begin{array}{l}\text { Composite } \\
\text { Reliability }\end{array}$ & $\begin{array}{l}\text { Average Variance } \\
\text { Extracted (AVE) }\end{array}$ & R Square Adjusted & Fornell-Larcker Criterion \\
\hline Goverment & 0.962 & 0.969 & 0.965 & 0.557 & & 0.746 \\
\hline Micro \& Small Business & 0.954 & 0.955 & 0.960 & 0.730 & 0.040 & 0.854 \\
\hline Workers & 0.959 & 0.966 & 0.963 & 0.583 & 0.314 & 0.764 \\
\hline Performance & 0.958 & 0.960 & 0.964 & 0.750 & 0.629 & 0.791 \\
\hline
\end{tabular}

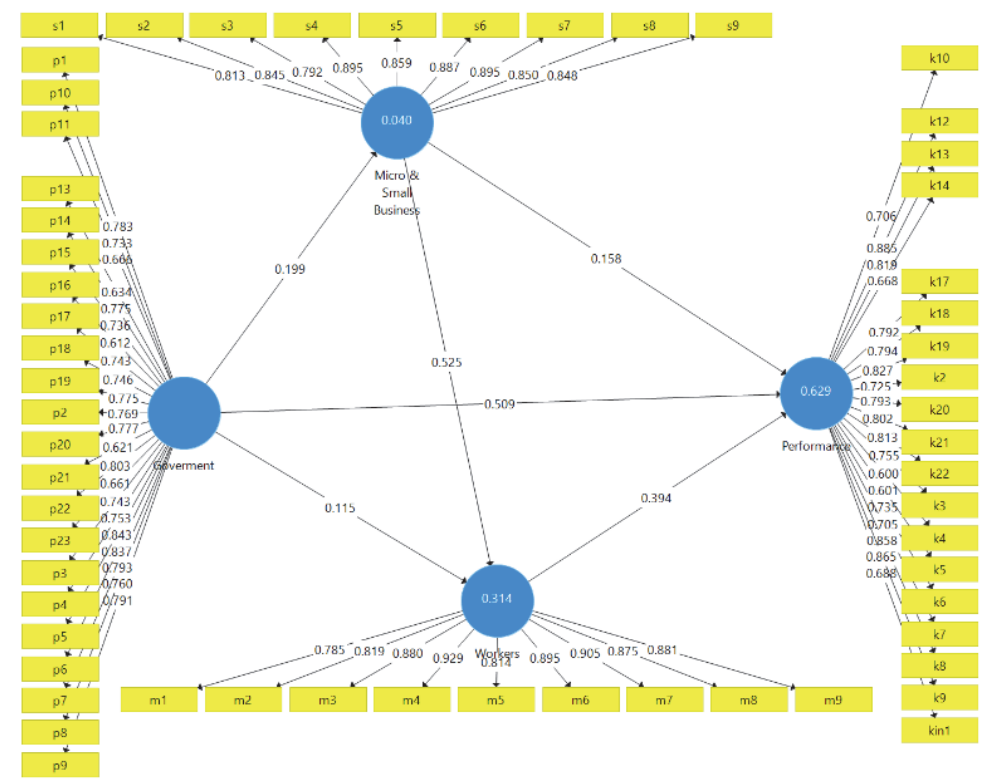

Fig. 2. Outer Model

\subsection{Inner Model: Direct and Indirect Effect}

The direct effect test results show that government role variables have a positive and not significant effect on micro and small business $(0.052>0.05)$. These results indicate that the government has not played a maximum role, so it has not had 
a significant impact on the participation of micro and small businesses to implement OHS. This condition shows the role of government, such as cooperation, must be increased again to be good. If there is no good coordination between the government and micro and small business, then the implementation of occupational health will not run well. This result is in line with research Manothum \& Rukijkanpanich, 2010; Puplampu \& Howard Quartey, 2012). Government role variables also have a positive and not significant effect on workers $(0.271>0.05)$. However, government variables have a positive and significant effect on Performance $(0.00<0.05)$. Micro and small businesses' role variables have a positive and significant effect on workers $(0.00<0.05)$. However, the role of micro and small business variables has a positive and not significant effect on Performance $(0.151>0.05)$. The worker's role variable has a positive and significant effect on Performance.

Table 3

Direct Effect

\begin{tabular}{|c|c|c|c|c|c|c|}
\hline & $\begin{array}{c}\text { Original } \\
\text { Sample (O) }\end{array}$ & $\begin{array}{c}\text { Sample } \\
\text { Mean (M) }\end{array}$ & $\begin{array}{c}\text { Standard } \\
\text { Deviation } \\
\text { (STDEV) }\end{array}$ & $\begin{array}{l}\text { T Statistics } \\
(|\mathrm{O} / \mathrm{STDEV}|)\end{array}$ & P Values & Hypothesis \\
\hline Goverment $\rightarrow$ Micro \& Small Business & 0.199 & 0.213 & 0.102 & 1.944 & 0.052 & Not Support \\
\hline Goverment $\rightarrow$ Workers & 0.115 & 0.117 & 0.105 & 1.103 & 0.271 & Not Support \\
\hline Goverment $\rightarrow$ Performance & 0.509 & 0.525 & 0.063 & 8.117 & 0.000 & Support \\
\hline Micro \& Small Business $\rightarrow$ Workers & 0.525 & 0.532 & 0.066 & 8.021 & 0.000 & Support \\
\hline Micro \& Small Business $\rightarrow$ Performance & 0.158 & 0.153 & 0.110 & 1.438 & 0.151 & Not Support \\
\hline Workers $\rightarrow$ Performance & 0.394 & 0.394 & 0.090 & 4.389 & 0.000 & Support \\
\hline
\end{tabular}

Source: Results of Research, 2020 (Processed Data).

The path direct effect test results show that the government's role has not maximized in empowering workers and employers. The government must collaborate with the two stakeholders. Cooperation is an entry point for collaboration. The motives of the economic strategy, such as subsidies, financing, and tax reduction, are some of the ways local governments can improve the company's OHS performance. In line with the research of Ghasemi, Mohammadfam, Soltanian, Mahmoudi, and Zarei (2015), which shows that providing incentives can improve compliance in carrying out OHS programs. The company can also offer bonuses or gifts for workers who provide many suggestions or input for the improvement and development of occupational health efforts. Through a detailed and precise OHS policy from the government, the implementation of OHS will run smoothly. The existence of legal and regulatory instruments will cause companies to be more serious about implementing OHS in the workplace. On the other hand, awareness and participation of workers will emerge to be more severe and active in the implementation of OHS. The low awareness and participation of workers caused by the lack of knowledge of workers, facilities, and OHS tools from the company and the promotion of occupational health and safety. Workers will prefer to work rather than be present to participate in health promotion and promotion. They are worried about losing their daily income from leaving their jobs.

Table 4

Specific and Total Indirect Effects

\begin{tabular}{|c|c|c|c|c|c|c|}
\hline Specific Indirect Effect & $\begin{array}{l}\text { Original } \\
\text { Sample }\end{array}$ & $\begin{array}{l}\text { Sample } \\
\text { Mean }\end{array}$ & $\begin{array}{l}\text { Standard } \\
\text { Deviation }\end{array}$ & $\begin{array}{l}\mathrm{T} \\
\text { Statistics }\end{array}$ & $\begin{array}{l}\mathrm{P} \\
\text { Values }\end{array}$ & Hypothesis \\
\hline Goverment $\rightarrow$ Micro \& Small Business $\rightarrow$ Performance & 0.032 & 0.031 & 0.029 & 1.096 & 0.273 & Not Support \\
\hline Goverment $\rightarrow$ Workers $\rightarrow$ Performance & 0.045 & 0.043 & 0.041 & 1.109 & 0.268 & Not Support \\
\hline $\begin{array}{l}\text { Goverment } \rightarrow \text { Micro \& Small Business } \rightarrow \text { Workers } \rightarrow \\
\text { Performance }\end{array}$ & 0.041 & 0.045 & 0.025 & 1.662 & 0.097 & Not Support \\
\hline Goverment $\rightarrow$ Micro $\&$ Small Business $\rightarrow$ Workers & 0.105 & 0.113 & 0.055 & 1.892 & 0.059 & Not Support \\
\hline Total Indirect Effect & & & & & & Not Support \\
\hline Goverment $\rightarrow$ Performance & 0.118 & 0.119 & 0.057 & 2.079 & 0.038 & Support \\
\hline Goverment $\rightarrow$ Workers & 0.105 & 0.113 & 0.055 & 1.892 & 0.059 & Not Support \\
\hline Micro \& Small Business $\rightarrow$ Performance & 0.207 & 0.210 & 0.058 & 3.580 & 0.000 & Support \\
\hline
\end{tabular}

Source: Results of Research, 2020 (Processed Data).

Specific indirect effect test results show that government variables have a positive and not significant effect on Performance through Micro \& Small businesses. (0.273>0.05). Government variables also have a positive and not significant effect on Performance through workers $(0.268>0.05)$. This result shows the weak collaboration between government, Micro \& Small businesses, and workers on Performance. However, the significance of government to Performance increases when through Micro \& Small businesses and workers (P-Value $=0.097)$. This result shows that if there is good collaboration between government, Micro \& Small businesses and workers will increase the significance value of the Performance variable. Government variables have a positive and not significant effect on workers through Micro \& Small Business $(0.059>0.05)$. However, when compared with the direct effect between government variables on workers $(\mathrm{P}$-value $=0.271)$, it shows that if collaboration occurs between government variables and Micro \& Small businesses, the significance value of the worker role will increase (0.271 to 0.059$)$. Specific indirect effect results indicate the need for a new approach to creating collaboration by designing governance among stakeholders. Collaboration between them will improve the performance of OHS officers for the better. The results of this study are in line with Bovaird and Loffler (2016), who show that new 
approaches to public service must be more democratic and well-managed. Good governance should be a collaborative approach, where the government is the leading player and the private sector as its agent (Donahue \& Zeckhauser, 2011). To realize this governance, the government must support a framework for building workers' participation from below and maintaining a firm commitment. This new approach carried out to involve the public and the private sector in the implementation of occupational health services. Therefore, the community must be actively involved in determining the desired service standards, public and private participation needed in the process, and management of services (Denhardt and Denhardt, 2007). Sutherland, Makin, and Cox (2000) have also warned that the traditional approach to safety in organizations has not had the expected impact on reducing the number of accidents in the workplace. They propose a new behavioral approach to managing safety and improving quality at work. Thus, the concepts of good governance and public service are related. Hawkins \& Rosete (2016) state that responsibility for public health and how the government intervenes in public health has changed. The policymaking process has also become increasingly complex. Thus, the government must develop a new governance approach to improve health policymaking.

Preacher and Hayes (2008) stated that the testing of the total indirect effect aims to determine whether overall, there is an influence of several mediating variables on the dependent variable. If an effect found, it can conclude that together with the mediator variables mediate the independent influence on the dependent. Thus, the bias towards estimation due to neglect of other variables in the model can be minimized. The total indirect effect test results show that government variables have a positive and significant effect on performance $(0.038<0.05)$. Thus, together Micro \& Small businesses and workers mediate government and performance. Government variables have a positive and not significant effect on Workers $(0.059>0.05)$. This result is in line with the results of testing on the specific indirect effect. Micro \& Small Business variables have a positive and significant effect on performance $(0.00<0.05)$. Thus, workers mediate Micro \& Small Business and Performance. These results differ indirect effect testing where Micro \& Small Business does not significantly influence performance. The role of Small business needs to be improved, especially in supervision, while the role of workers that needs to be improved is planning and supervision.

This condition shows that Small businesses and workers must care and commit to carrying out the OHS program. Small business is responsible for supervising and facilitating workers in carrying out OHS in the workplace. Because healthy workers will increase business productivity. In order for OHS Oversight and implementation to run effectively requires a stable policy framework, so that it benefits all parties, both small businesses and workers and the government. Based on the results of descriptive statistics, it can be seen that the roles played by stakeholders are not yet maximal. Thus a collaborative approach to health governance and worker safety is an important issue to be implemented immediately. Stakeholders can do co-creation and collaboration through sharing resources.

Table 5

Total Effects

\begin{tabular}{|c|c|c|c|c|c|c|}
\hline & $\begin{array}{c}\text { Original } \\
\text { Sample }(\mathrm{O})\end{array}$ & $\begin{array}{c}\text { Sample Mean } \\
\text { (M) }\end{array}$ & $\begin{array}{c}\text { Standard } \\
\text { Deviation } \\
\text { (STDEV) }\end{array}$ & T Statistics & P Values & Hypothesis \\
\hline Goverment $\rightarrow$ Micro \& Small Business & 0.199 & 0.213 & 0.102 & 1.944 & 0.052 & Not Support \\
\hline Goverment $\rightarrow$ Performance & 0.628 & 0.645 & 0.064 & 9.752 & 0.000 & Support \\
\hline Goverment $\rightarrow$ Workers & 0.220 & 0.230 & 0.118 & 1.871 & 0.062 & Not Support \\
\hline Micro \& Small Business $\rightarrow$ Performance & 0.365 & 0.363 & 0.086 & 4.255 & 0.000 & Support \\
\hline Micro \& Small Business $\rightarrow$ Workers & 0.525 & 0.532 & 0.066 & 8.021 & 0.000 & Support \\
\hline Workers $\rightarrow$ Performance & 0.394 & 0.394 & 0.090 & 4.389 & 0.000 & Support \\
\hline
\end{tabular}

Source: Results of Research, 2020 (Processed Data).

The results of the Total effect test show that government variables have a positive and not significant effect on Micro \& Small Business $(0.052>0.05)$. Government variables have a positive and significant effect on Performance $(0.00<0.05)$. Government variables have a positive and not significant effect on workers $(0.062>0.05)$. Micro \& Small Business variables have a positive and significant effect on Performance $(0.00<0.05)$. Micro \& Small Business variables have a positive and significant effect on workers $(0.00<0.05)$. Worker variables have a positive and significant effect on Performance $(0.00$ $<0.05$ ). If we compare the test results on the direct effect and the specific indirect effect, we will see a positive and significant increase in the role of the government. These results reinforce that the role of government is the more positive impact and significant after collaboration. Collaboration on the role of the government can be done directly through organizations that have basic tasks and functions related to OHS, such as the City Health Office, Manpower Office, Institute of Occupational Safety and Health, and Institute of Social Security Employmet. However, it can also be done indirectly through the industry and trade department, an integrated licensing service agency that deals with small industries and business licensing.

\subsection{Discussion}

Collaboration by creating good governance will improve performance in occupational safety and health. Song and Mu (2013) stated that the role of stakeholders would improve the implementation of occupational health and safety (OHS), especially policies related to OHS. Althaqafi and Abunar (2017) state that stakeholder involvement will improve performance in carrying out OHS. A similar opinion was also expressed by Pi, Gao, Chen, \& Liu (2019) that the joint efforts of stakeholders will improve performance in the OHS. According to Gravelle, Baird, \& Green (2008), complex collaborative 
models generated through vertical approaches at the governmental and horizontal levels involving various public and private actors. Some collaboration principles that need to consider are how to determine the needs of these partners. What type of collaborative approach should be chosen to make it right on target. The low level of Cooperation is caused by the lack of interaction and communication between stakeholders so that coordination between institutions becomes weak. The collaboration will be created and run well if communication between stakeholders carried out regularly and continuously. of course, it must reduce sectoral egos and promote shared interests. Ndjoulou et al. (2015) say that collaboration will become stronger if supported by secure communication and interaction between stakeholders. Irimie et al. (2015) mentioned that it needed an integrated, coordinated, and strategic response and collaboration between the sections with significant interests. Schuman (2006) suggested that to build a culture of collaboration, and it is necessary to align goals for the achievement of a shared vision and mission, and a commitment to continue learning and working in teams and responsibilities between the organization and employees. New findings in this research show that the concept of governance with a collaborative approach consisting of elements of local government, city health office, business owners, and worker representatives will be more effective. The team must be formed in stages starting from the sub-district level to the city. Thus, communication and coordination will run effectively and smoothly. OHS policy is needed that forms the basis of regulations, like decisions or regulations of the mayor related to the implementation of the OHS program in Medan. Dwomoh, Owusu, and Addo (2013) mentioned that with the policy issued by the government, all teams involved in occupational health groups could carry out their duties better. Besides, the collaboration will occur, for instance, sharing resources related to OHS training, testing the work environment, health checks, and other activities that can support the implementation of occupational health efforts, to encourage the performance of OHS officers.

Schmidt et al. (2015) said that collaboration is a joint arrangement and requires stakeholder involvement in realizing occupational health services. Collaboration is the key to the successful implementation of the program as long as taking into account several factors, namely trust between the parties involved, joint commitment, building relationships at different organizational levels, a well-structured company work environment for health and safety management, occupational safety and health consultative in prevention and promotion activities as well as mutual benefits. The availability of OHS HR personnel scattered in each district is a strength for the Health Office and community health center to carry out occupational health programs. Also, adequate OHS equipment for testing the work environment and functional staff is at the OHS Center and the Manpower Office. Sharing existing resources among stakeholders is one of the strategies in developing health efforts in the City of Medan. This strategy can be an example for other regions in optimizing OHS performance. Some of the challenges of creating collaboration in the OHS program in Medan are the lack of trust and cooperation from the company to OHS officers. Another challenge that occurs in the field is that it is difficult for OHS officers to enter the business location. The stereotypical impression that OHS officers who come to the location will disrupt business operations find faults in OHS management and ask for funding for OHS management. Thus, the government's role as a catalyst is needed to convince business owners that OHS management based on the application of good governance. The basic principle of good governance is the involvement of three parties in the service process, namely the local government, companies, and community elements, as service users can implement well. Auvinen et al. (2012) stated that health promotion in modern workplaces requires collaboration, partnerships, and alliances with internal and external stakeholders. Lydell et al. (2017) suggested the need for proactive collaboration between governments, companies, and workers to implement and achieve the goals of occupational health services. Their results show the urgency of implementing health promotion in the workplace. The results also show that intervention for workers is essential. Collaboration between business owners and workers in the workplace is necessary to prevent and reduce workplace accidents. As the findings in this study, one of the collaborative strategies between the government, the private sector, and the workers in improving the OHS program through the concept of revitalizing the occupational health post and forming cadres plus. Cadre Plus functions to educate and increase worker awareness in terms of occupational health and safety programs. Cadre plus will be the spearhead of the implementation of OHS in the workplace. Thus, awareness and initiatives to safeguard the health and safety of workers emerge from themselves.

\section{Limition of research and Conclusion}

This research only involves OHS officers in the main CHC, it needs to involve OHS officers in the working area of the branch of $\mathrm{CHC}$, so there can be more samples. Mixed methods need to be developed to dig deeper into the collaboration needs needed to improve staff performance and the obstacles that have faced. The OHS program's application at the CHC is still new, so that its implementation has not yet run optimally.

Direct test results show that the role of government directly influences the performance of OHS officers. The role of the Workers directly affects the performance of OHS officers. The role of micro \& small business does not affect officers' performance, but the role of micro \& small business affects the role of workers. The role of government has no direct effect on workers, but if through small businesses, the significance value will increase to 0.059 . This result shows the importance of collaboration between stakeholders. Revitalization of the roles of each stakeholder is needed to improve performance. Good governance with a stakeholder collaboration approach to complement and strengthen the cooperation function. In addition to increasing cooperation between governments, micro \& small business, and workers, the collaboration between governments is essential. Collaboration between governments, involving the Manpower Office, the Institute of Occupational Safety and Health, and the Institute of Social Security Employment is essential. In this collaboration, the City Health Office is a leading sector, because the OHS program integrated into the CHC is the responsibility of this service. 


\section{References}

Adan, I. H. (2012). Influence of stakeholders role on performance of constituencies development fund projects a case of Isiolo North Constituency, Kenya (Doctoral dissertation, University of Nairobi, Kenya).

Ahmad, I. (2017). Workplace Safety And Health Conditions And Facilities In Small Industries In Jeddah, Saudi Arabia, Journal of Safety Studies, 3(1). https://Doi.Org/10.5296/Jss.V3i1.11104

Althaqafi, T., \& Abunar, S. (2017). Stakeholder role in safety culture and safety. Journal, Global Resource, Human Vol, Management Centre, European Uk, Development, 5(6), 36-48.

Amstrong, M. (2006). Performance Management (Edisi Ke-3). London Dan Philadelphia: Thomson-Shore, Inc.

Andersen, J. H., Malmros, P., Ebbehoej, N. E., Flachs, E. M., Bengtsen, E., \& Bonde, J. P. (2019). Systematic literature review on the effects of occupational safety and health $(\mathrm{OSH})$ interventions at the workplace. Scandinavian Journal Of Work, Environment And Health, 45(2), 103-113. Https://Doi.Org/10.5271/Sjweh.3775

Auvinen, A. M., Kohtam̈Aki, K., \& Ilvesm̈Aki, A. (2012). Workplace health promotion and stakeholder positions: A finnish case study. Archives Of Environmental And Occupational Health, 67(3), $177-184$. https://Doi.Org/10.1080/19338244.2011.598892

Baumfield, V. S. (2016). Stakeholder theory from a management perspective: Bridging the shareholder/stakeholder divide. Australian Journal Of Corporate Law, 31, 187-207.

Beriha, G. S., Patnaik, B., \& Mahapatra, S. S. (2011). Safety performance evaluation of Indian organizations using data envelopment analysis. Benchmarking, 18(2), 197-220. Https://Doi.Org/10.1108/14635771111121676

Bovaird, T., \& Loeffler. Elke. (2016). Public Management And Governance (3rd Edition). Routledge.

Buijs, P., \& Dijk, F. Van. (2014). Essential Interventions On Workers' Health By Primary Health Care A Scoping Review Of The Literature : A Technical Report Essential Interventions On Workers' Health By Primary Health Care A Scoping Review Of The Literature :, (March).

Buijs, P., Gunnyeon, B., \& Weel, C. Van. (2012). Primary health care: What role for occupational health? British Journal Of General Practice, 63(608), 124. Https://Doi.Org/10.3399/Bjgp13x664108

Burton, J. (2010). Healthy Workplace Framework And Model: Background And Supporting Literature And Practices. World Health Organization, 1-131. Https://Doi.Org/10.1109/VLSIT.2007.4339737

Buse, K., Mays, N., \& Walt, G. (2012). Making Health Policy (Second Edi). UK: Mcgraw-Hill Education.

Cagno, E., Micheli, G. J. L., \& Perotti, S. (2011). Identification of OHS-Related factors and interactions among those and OHS performance in SMEs. Safety Science, 49(2), 216-225. Https://Doi.Org/10.1016/J.Ssci.2010.08.002

Cameron, I., \& Hare, B. (2013). An analysis of safety advisor roles and site safety performance. Engineering, Construction And Architectural Management, 20(5), 505-521.

Cascio, W. F., \& Aguinis, H. (2008). 3 staffing twenty-first-century organizations. Academy Of Management Annals, 2(1), 133-165. Https://Doi.Org/10.5465/19416520802211461

Charalabidis, Y., \& Koussouris, S. (Eds.). (2012). Empowering Open And Collaborative Governance. London.

Chen, Y., Chen, J., Sun, Y., Liu, Y., Wu, L., Wang, Y., \& Yu, S. (2010). Basic occupational health services In Baoan, China. Journal Of Occupational Health, 52(1), 82-88.

Chin, W. W. (1998). The Partial Least Squares Aproach to Structural Equation Modeling. Modern Methods for Business Research, 295, 336. London: Lawrence Erlbaum Associates.

Curcuruto, M. (2016). Safety Participation in the workplace: An assessment tool of proactive safety orientations by individuals ( PRO-SAFE ). Chemical Engineering Transactions, 53, 181-186. Https://Doi.Org/10.3303/CET1653031

Denhardt, R. B \& Denhardt, J.V (2007). The New Public Service: Serving Not Steering. M.E. Sharpe, Inc, New York.

Denny, H. M. (2012). Impact Of Occupational Health Interventions In Indonesia. Proquest Dissertations And Theses, (January), 152-N/A. Retrieved From Http://Search.Proquest.Com/Docview/1283390488?Accountid=13771

Dessler, G. (2017). Human Resaurce Management (15th Ed.). Boston: Pearson.

Dijk, F. Van, \& Buijs, P. (2017). Manual for primary health care on basic occupational health services. Encouraging publication from India, focused on informal occupations. Asia Pacific Family Medicine, 16(1), 2-5. Https://Doi.Org/10.1186/S12930-017-0032-8

Doloi, H. (2012). Assessing stakeholders' influence on social performance of infrastructure projects. Facilities, 30(11), 531-550. Https://Doi.Org/10.1108/02632771211252351

Donahue, J. ., \& Zeckhauser, R. J. (2011). Collaborative Governance ; Private Roles For Public Goals In Turbulent Times. New Jersey: Princeton University Press.

Dwomoh, G., Owusu, E. E., \& Addo, M. (2013). Impact Of occupational health and safety policies on employees' performance in the Ghana's timber industry: Evidence From Lumber And Logs Limited. International Journal Of Education And Research, 1(12), 1-14.

EU-OSHA. (2012). Healthy Workplaces Working Together For Risk Prevention Worker Participation In Occupational Safety And Health.

Ferdiana, A., Baiquni, F., Rahman, D. U., Febriana, A., Solikhah, S., Nervila, A. V., ... Dewi. (2019). Implementation Of Community Based Occupational Health Programs For Informal Workers In Indonesia. Occup Environ Med, 76(Suppl 1), 2019.

Freeman, R. E., Harrison, J. S., Wicks, A. C., Parmer, B. L., \& Colle, S. De. (2010). Stakeholder Theory: The Satate Of The Art. New York: Cambridge University Press.

Frieden, T. R. (2013). Government's Role In Protecting Health And Safety. The New England Journal Of Medicine, 
368(20), 2013-2015.

Ghasemi, F., Mohammadfam, I., Soltanian, A. R., Mahmoudi, S., \& Zarei, E. (2015). Surprising incentive : An instrument for promoting safety performance of construction employees. Safety And Health At Work, 6(3), $227-232$. Https://Doi.Org/10.1016/J.Shaw.2015.02.006

Ghuzdewan, T., \& Damanik, P. (2019). Analysis of accident in Indonesian construction projects, 2021, 1-6. Https://Doi.Org/Https://Doi.Org/10.1051/Matecconf/201925802021

Gravelle, M., Baird, K., \& Green, I. (2008). Changing Federal Roles Collaborative Governance And Changing Federal Roles.

Hair, J. J. F., Hult, G. T. M., Ringle, C. M., \& Sarstedt, M. (2017). A Primer On Partial Least Squares Structural Equation Modeling (PLS-SEM). Calofornia: SAGE Publication.

Halonen, J. I., Atkins, S., Hakulinen, H., Pesonen, S., \& Uitti, J. (2017). Collaboration between employers and occupational health service providers: A systematic review of key characteristics. BMC Public Health, 17(1), 1-9. Https://Doi.Org/10.1186/S12889-016-3924-X

Harris, L.-A., Olsen, K. B., \& Walker, R. J. (2012). Role typology for health and safety. Employee Relations, 34(Iss 5), 481-500.

Harrison, J. S., \& Wicks, A. C. (2013). Stakeholder theory, value, and firm performance. Business Ethics Quarterly, 23(1), 97-124. Https://Doi.Org/10.5840/Beq20132314

Hawkins, B., \& Alvarez-Rosete, A. (2016). Role Of The State In Public Health Policy. International Encyclopedia Of Public Health. Elsevier Inc. Https://Doi.Org/10.1016/B978-0-12-803678-5.00462-8

Health, M., Goals, S. D., WHO Regional Office For Europe, \& Figure, S. (2001). The role of the occupational health nurse in workplace health management. Occupational Health, (C), 1-4. Https://Doi.Org/10.15713/Ins.Mmj.3

Irimie, S., Munteanu, R., Ghicajanu, M., \& Marica, L. (2015). Aspects of the safety and health at the workplace. Procedia Economics And Finance, 23(October 2014), 152-160. Https://Doi.Org/10.1016/S2212-5671(15)00390-1

Jahangiri, M., Rostamabadi, A., Yekzamani, P., Mahmood Abadi, B., Behbood, F., Ahmadi, S. F., \& Momeni, Z. (2016). A descriptive study of occupational health services in self-employed enterprises (Nanoscale Enterprises), Shiraz, Iran. Safety And Health At Work, 7(4), 317-321. Https://Doi.Org/10.1016/J.Shaw.2016.05.004

Kelloway, E. K., \& Cooper, C. L. (2011). Occupational Health And Safety For Small And Medium Sized Enterprises. (E. K. Kelloway \& C. L. Cooper, Eds.). Massachusetts: Edward Elgar Publishing Limited.

Laal, F., Pouyakian, M., Madvari, R. F., Khoshakhlagh, A. H., \& Halvani, G. H. (2019). Investigating the impact of establishing integrated management systems on accidents and safety performance indices: A case study. Safety And Health At Work, 10(1), 54-60. Https://Doi.Org/10.1016/J.Shaw.2018.04.001

Lane, B., Leader, P., Bell, J., Smith, P., \& Worth, J. (2000). Employee Involvement In Health And Safety : Some Examples Of Good Practice. Human Factors (Vol. 44).

Ledikwe, J. H., Kleinman, N. J., Mpho, M., Mothibedi, H., Mawandia, S., Semo, B., \& Malley, G. O. (2018). Associations between healthcare worker participation in workplace wellness activities and job satisfaction, occupational stress and burnout: A Cross- Sectional Study In Botswana. BMJ Open, (8:E018492), 1-7. Https://Doi.Org/10.1136/Bmjopen2017-018492

Ling, F. Y. Y., Zhang, Z., \& Guo, L. (2019). Measures to regain productivity after construction accidents, 719-724. Https://Doi.Org/10.3311/Ccc2019-098

Lydell, M., Hildingh, C., Söderbom, A., \& Ziegert, K. (2017). Future challenges for occupational health services can be prevented by proactive collaboration with the companies using the services: A participatory and reflection project. Journal Of Multidisciplinary Healthcare, 10, 217-225. Https://Doi.Org/10.2147/JMDH.S131382

Mandal, A. K. (2009). Strategies and policies deteriorate occupational health situation in India: A review based on social determinant framework. Indian Journal of Occupational and Environmental Medicine, 13(3), 113.

Manothum, A., \& Rukijkanpanich, J. (2010). A participatory approach to health promotion for informal sector workers in Thailand. Journal Of Injury \& Violence Research, 2(2), 111-120. Https://Doi.Org/10.5249/Jivr.V2i2.36

Mchunu, G. (2012). Proposed guidelines gor a workplace health promotion policy and implementation framework. Occupational Health Southern Africa, 18(2), 5-12.

Micheli, G. J. L., \& Cagno, E. (2010). Dealing With Smes As A Whole In OHS Issues: Warnings From Empirical Evidence. Safety Science, 48 (6), 729-733.

Ministry of Cooperatives and SMEs RI (2020) Development Of Micro, Small, Medium And Big Business, Business Data Development, retrieved From http://www.depkop.go.id/data-umkm.

Ministry of Health RI (2017). Performance Report of Government Agencies (Lakip) Directorate of Occupational Health and Sports 2015. Retrieved From Http://Wep.Depkes.Go.Id/Resources/Download/LAKIP ROREN / 3 Performance Report / BIGIKIA / LAKIP 2015 Dit. Occupational Health \& OR.Pdf.

Ministry of Health RI (2007). Guidelines for Occupational Health Services at Regional Health Centers / Industrial Centers, No.038 / Menkes / SK / I / 2007. Indonesia.

Ministry of Health RI (2010). Guidelines for the Development of Occupational Health Efforts in Pilot Districts / Cities in the Field of Occupational Health. Jakarta: Directorate of Occupational Health Development.

Ministry of Health RI(2015). Republic of Indonesia Minister of Health Regulation No. 100 Year 2015 Concerning Integrated Work Health Posts, (9), 1-26.

Muda, I; M. Weldi; Siregar, H.S, \& Indra, N. (2018). The analysis of effects of good corporate governance on earnings 
management in Indonesia with panel data Approach. Iranian Economic Review. 22(2). 657-669.

Muda, I., \& Wahyuni, E. (2019). An analysis on the effect of environmental performance and the implementation of environmental management system (ISO 14001) on the issuer financial performance. Calitatea, 20(168), 113-117.

Mohammadfam, I., Kamalinia, M., Momeni, M., Golmohammadi, R., Hamidi, Y., \& Soltanian, A. (2016). SC. Safety And Health At Work. Https://Doi.Org/10.1016/J.Shaw.2016.09.001

Mohammadfam, I., Kamalinia, M., Momeni, M., Golmohammadi, R., Hamidi, Y., \& Soltanian, A. (2017). Evaluation of the quality of occupational health and safety management systems based on key performance indicators in certified organizations. Safety And Health At Work, 8(2), 156-161. Https://Doi.Org/10.1016/J.Shaw.2016.09.001

Mojapelo, J. M., \& Mafini, C. (2016). Employee Perceptions Of Occupational Health And Safety, (December 2019).

Ndjoulou, F., Desmarais, L., \& Pérusse, M. (2015). Employer responsibility for occupational health and safety: Challenges, issues and approaches. Journal Of Management Policies And Practices, 3(1), 1-8. Https://Doi.Org/10.15640/Jmpp.V3n1a1

Pawłowska, Z. (2015). Using lagging and leading indicators for the evaluation of occupational safety and health performance in industry. International Journal Of Occupational Safety And Ergonomics, 21(3), $284-290$. Https://Doi.Org/10.1080/10803548.2015.1081769

Pi, Z., Gao, X., Chen, L., \& Liu, J. (2019). The New Path To Improve Construction Safety Performance In China: An Evolutionary Game Theoretic Approach. Https://Doi.Org/10.3390/Ijerph16132443.

Preacher, K. J., \& Hayes, A. F. (2008). Contemporary approaches to assessing mediation in communication research. In A. F. Hayes, M. D. Slater, \& L. B. Snyder (Eds.), The Sage sourcebook of advanced data analysis methods for communication research (p. 13-54). Sage Publications, Inc. https://doi.org/10.4135/9781452272054.n2

Puplampu, B. B., \& Quartey, S. H. (2012). Key issues on occupational health and safety practices in Ghana: A review. International Journal Of Business And Social Science, 3(19), 151-157.

Putri, A. S. (2013). Keselamatan Dan Kesehatan Kerja Sebelum Dan Sesudah Penerapan. Jurnal Bisnis Dan Strategi, 22(1), 67-94.

Rafiei, M., Ezzatian, R., Farshad, A., Sokooti, M., Tabibi, R., \& Colosio, C. (2015). Occupational health services integrated in primary health care in Iran. Annals Of Global Health, 81(4), 561-567. Https://Doi.Org/10.1016/J.Aogh.2015.08.020

Rantanen, J. (2007). Basic Occupational Health Services. (S. Lehtinen, Ed.), This Basic Guideline Has Been Published As A Response To The Joint ILO/WHO Committee On Occupational Health Priority Area For ILO/WHO/ICOH Collaboration, With Support Of The Finnish Institute Of Occupational Health (FIOH). (3rd, Revis Ed.). Helsinki.

Rantanen, J. (2005). Basic Occupational Health Services - Their Structure, Content And Objectives. Scandinavian Journal Of Work, Environment And Health, Supplement, 1, 5-15.

Rantanen, Jorma, Lehtinen, S., \& Iavicoli, S. (2013). Occupational health services in selected international commission on occupational health (ICOH) member countries. Scandinavian Journal Of Work, Environment And Health, 39(2), 212216. Https://Doi.Org/10.5271/Sjweh.3317

Sachs, S., \& Ruhli, E. (2011). Stakeholders Matter. Stakeholders Matter. Https://Doi.Org/10.1017/Cbo9781139026963

Schmidt, L., Sjöström, J., \& Antonsson, A. B. (2015). Successful collaboration between occupational gealth service providers and client companies: Key factors. Work, 51(2), 229-237. Https://Doi.Org/10.3233/WOR-141855

Schuman, S. (Ed.). (2006). Creating A Culture Of Collaboration. San Francisco: Jossey Bass.

Shankar Beriha, G., Patnaik, B., \& Shankar Mahapatra, S. (2012). Assessment of occupational health practices in Indian industries: A neural network approach. Journal Of Modelling In Management, 7(2), $180-200$. Https://Doi.Org/10.1108/17465661211242804

Silverberg, N. D., Panenka, W. J., \& Iverson, G. L. (2018). Work productivity loss after mild traumatic brain injury. Archives Of Physical Medicine And Rehabilitation, 99(2), 250-256. Https://Doi.Org/10.1016/J.Apmr.2017.07.006

Soehod, K. (2008). Workers' participation in safety and health at work. Jurnal Kemanusiaan, 11, 15-23.

Somad, I. (2013). Teknik Efektif Dalam Membudayakan Keselamatan Dan Kesehatan Kerja. Jakarta: Dian Rakyat.

Song, X., \& Mu, X. (2013). The safety regulation of small-scale coal mines in China: Analysing the interests and influences of stakeholders. Energy Policy, 52, 472-481. Https://Doi.Org/10.1016/J.Enpol.2012.09.069

Soucie, J. M. (2012). Public health surveillance and data collection: general principles and impact on hemophilia care. Hematology, 17(sup1), s144-s146.

Sutherland, V. J., Makin, P. ., \& Cox, C. . (2000). The Management Of Safety The Behavioural Approach To Changing Organizations. London, Thousand Oaks, New Delhi: SAGE Publications.

Syahri, Isyatun, M., \& Fitria, M. (2019). The Activity Of Occupational Health Effort On Five Occupational Health Posts ( Pos UKK ) In Medan, 2019(2010), 333-338. Https://Doi.Org/10.18502/Kls.V4i10.3803

Syahri, Isyatun, M., \& Fitria, M. (2018). Keselamatan Dan Kesehatan Kerja ( K3 ) Pada Nelayan Di Pos Upaya Kesehatan Kerja ( Pos Ukk ) Puskesmas Belawan TALENTA Conference Series Keselamatan Dan Kesehatan Kerja ( K3 ) Pada Nelayan Di Pos. TALENTA Conference Series: Tropical Medicine (TM), 1(1), 202-206.

Tai, J. C. F., Wang, K., \& Chang, H. L. (2014). How Coaligned Stakeholder Support Enhances End User's Perceived ERP Performance? The Pivotal Role Of ERP Identity. Proceedings Of The Annual Hawaii International Conference On System Sciences, 4474-4483. Https://Doi.Org/10.1109/HICSS.2014.551

Vinberg, S., Hansen, E., Hedlund, M., \& Landstad, B. (2017). Ambiguity among managers in small-scale enterprises: How to handle business and workplace health management. Societies, 7(4), 31. Https://Doi.Org/10.3390/Soc7040031

Vinberg, S., Torsdatter Markussen, L., \& Landstad, B. J. (2017). Cooperation between occupational health services and small-scale enterprises in Norway and Sweden: A provider perspective. Workplace Health And Safety, 65(8), 355-364. 
Https://Doi.Org/10.1177/2165079916668527

Walters, D., \& Wadsworth, E. (2017). Worker Participation In The Management Of Occupational Safety And Health : Qualitative Evidence From ESENER-2 European Risk Observatory. Luxembourg: Publications Office Of The European Union. Https://Doi.Org/10.2802/93677

Yazdani, A., Hilbrecht, M., Imbeau, D., Bigelow, P., Patrick, W., Pagell, M., ... Management, P. (2017). Key Informants ' Perspectives : Management Commitment, Training, And Worker Participation In The Prevention Of Musculoskeletal Disorders Key Informants 'Perspectives : Management Commitment, Training, And Worker Participation In The Prevention Of Mus. IISE Transactions On Occupational Ergonomics And Human Factors, 5838(November). Https://Doi.Org/10.1080/24725838.2017.1386142

Zulkifly, S. S. (2018). Worplace safety improvement sn SME manufacturing : A government intervention. International Journal of Science and Technology, 4(2), 27-39.

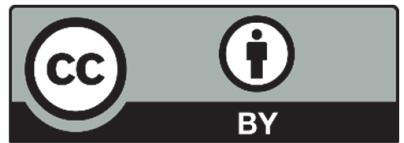

(C) 2021 by the authors; licensee Growing Science, Canada. This is an open access article distributed under the terms and conditions of the Creative Commons Attribution (CC-BY) license (http://creativecommons.org/licenses/by/4.0/). 